\title{
The quantitative significance of long-term regulation of food intake in the cow
}

\author{
By J. A. BINES, S. SUZUKI* and C. C. BALCH \\ National Institute for Research in Dairying \\ Shinfield, Reading, Berks
}

(Received 22 fanuary 1969-Accepted 20 March 1969)

\begin{abstract}
I. Six adult, non-pregnant, non-lactating, Friesian cows were used when fat and when thin to measure differences in the voluntary intakes of straw, hay and hay plus concentrates caused by the fatness of the animals. Measurements of digestibility, time of retention of food in the digestive tract, rate of breakdown of cotton threads in the ventral sac of the rumen and amounts of digesta in the reticulo-rumen were included.

2. The mean voluntary intakes of straw were similar for fat and thin cows. In absolute terms, thin cows consumed $31 \%$ more hay and $23 \%$ more hay and concentrates than fat cows; in relation to metabolic body size $\left(\mathrm{W}^{0.75}\right)$, these differences were $76 \%$ and $52 \%$ respectively.

3. Small decreases in digestibility of these diets by the thin cows, reflected in slight reductions in the rate of loss of weight of cotton threads placed in the rumen, did not alter the significance of the differences in intake between fat and thin cows.

4. Small changes in time of retention of food in the digestive tract suggested that the capacity of the tract may have been greatest in the thin cows.

5. The presence of a greater amount of digesta in the reticulo-rumen of thin cows than in that of fat cows after eating hay supports the suggestion of a greater gut capacity in these animals. In both fat and thin cows, the capacity of the reticulo-rumen did not appear to have limited the intake of the hay and concentrate diet. In both groups the lowest levels of rumen fill were observed after straw was given.

6. The results are discussed in terms of possible mechanisms which may operate to reduce the voluntary intake of medium- and good-quality diets as cows become fatter. When poorquality roughages are given, other factors appear to conceal any differences in intake which may exist between fat and thin cows.
\end{abstract}

It is well known that in adult man and adult animals body-weight is usually maintained at more or less constant levels, sometimes for very long periods of time. Thus a long-term regulation of food intake must have an important and precise role. As a possible mechanism bringing about such control, (Kennedy, 1953) postulated a 'lipostatic' theory of regulation of voluntary food intake. This theory proposes that some compound, released from the fat depots in proportion to their total size, inhibits food intake. Thus, over a period of time, food intake is gradually reduced as the animal becomes fatter, until eventually only the maintenance requirement of the animal will be met, and the animal will thus gain no further weight.

The quantitative effects of such a mechanism in ruminants are not clear. Schinckel ( 1960 ) observed a progressive decline in the ad lib. intake of grazing sheep, which was associated with increasing bodily fatness. However, this was confounded with an increase in environmental temperature during the last part of the experiment. He refers also to a syndrome in extremely fat sheep in which some unknown factor precipitates a complete refusal to eat. The animals lose weight and usually die in

* Present address: Dairy Science Department, Obihiro Zootechnical University, Obihiro, Hokkaido, Japan. 
2-4 weeks, very ofter with substantial quantities of omental and mesenteric fat remaining. Hutton (1963) found that dry cows, offered fresh pasture herbage under stall-feeding conditions, achieved a high intake $(2 \cdot 17 \mathrm{~kg}$ dry matter/100 $\mathrm{kg}$ live weight per day) which was reflected in a rapid rate of growth and fattening. This was followed by a decline in appetite as a maximum degree of fatness was approached until finally intake was reduced to $1.56 \mathrm{~kg}$ dry matter/roo kg live weight per day, which was sufficient only for the maintenance of these very fat animals. Here again, the implications are somewhat obscured by the inclusion in the experiment of young animals which were still growing.

The main object of the present study was to obtain, in adult dairy cows, information on the extent to which the appetite of thin cows exceeds that of fat cows when there are no complications due to changes in growth, milk production or environment. It was also considered that some indication of the mode of operation of the mechanism involved might be obtained by feeding $a d$ lib., to fat cows and thin cows, three different rations, straw, hay and hay plus concentrates; the intakes of these foods are thought to be controlled to relatively different extents by physical and chemical factors (Freer \& Campling, r 963 ; Conrad, Pratt $\&$ Hibbs, I964). In conjunction with measurements of rumen fill, it was expected that these observations would give an indication of the extent to which the mechanism may be physical or chemical in nature.

\section{EXPERIMENTAL}

A double changeover experiment was used to compare the following treatments each applied to six cows when fat and when thin:

(a) oat straw ad lib.

(b) hay ad lib.

(c) $3 \mathrm{~kg}$ hay and concentrates ad lib.

At the beginning of each part of the experiment three cows were fat and three were thin; the sole criterion of fatness and thinness was live weight, the mean for the thin animals being $433 \mathrm{~kg}$, and that for the fat animals $610 \mathrm{~kg}$ (see Table 2). The diets were fed in successive experimental periods, in the above order to the thin cows, and in the reverse order to the fat cows. The fixed sequences were adopted to facilitate the most rapid changeovers between diets, thus permitting the intakes of all diets to be measured in a given animal in a given state with a minimum change in the live weight.

Each group of three cows was left on the final diet for $15^{-25}$ weeks for the thin cows to become fat, and the fat cows thin; cows were considered to be fat when they had reached a constant maximum live weight and had maintained this weight for at least 4 weeks. The treatments were then re-applied to each group. This procedure ensured that fat and thin cows were exposed equally to any variations in environment.

An experimental period consisted of $\mathrm{r}_{4}$ days for adjustment to the diet ( 28 days when the change was from hay to hay plus concentrates or vice versa), Io days during which voluntary intake and digestibility were measured, 3 days recording feeding behaviour (this information is not presented in this paper) and 2 days on which the fill in the reticulo-rumen was measured, and live weights were recorded. 


\section{Cows and housing}

The cows were non-pregnant, non-lactating Friesians, each fitted with a permanent rumen fistula closed by a rubber cannula and bung. The average age of the animals at the start of the experiment was 73 months (range $5{ }^{1-97)}$; it was therefore assumed that they were fully grown. The cows were housed in individual standings in a metabolism house. The mean maximum daily temperature was $18.3^{\circ}$ (range $12-27^{\circ}$ ) and the mean minimum was $15^{\circ} 4^{\circ}$ (range $\left.10-23^{\circ}\right)$. Water and salt licks containing trace minerals were available at all times; $50 \mathrm{~g}$ of a mineral mixture and $60 \mathrm{~g}$ of a supplement containing vitamins $\mathrm{A}$ and $\mathrm{D}$ were administered through the fistula once weekly.

\section{Foods}

The hay was predominantly perennial ryegrass. The concentrates were in the form of cubes and their composition was ( $\mathrm{g} / \mathrm{I00} \mathrm{g})$ : barley 17 , maize 20 , wheat bran 20 , decorticated groundnut meal I5, copra cake 10, palm-kernel cake 5, molasses 10, dicalcium phosphate $\mathbf{I}$, calcium carbonate $\mathrm{I}$ and sodium chloride $\mathrm{I}$, with $5 \times 10^{6}$ i.u. vitamin $\mathrm{A}$ and $\mathrm{I} \times 10^{6}$ i.u. vitamin $\mathrm{D}$ added per $1000 \mathrm{~kg}$. The proximate composition of the foods is shown in Table $\mathrm{I}$.

Table r. Chemical composition of the foods

\begin{tabular}{|c|c|c|c|c|c|c|c|}
\hline & $\begin{array}{c}\text { Dry } \\
\text { matter }\end{array}$ & $\begin{array}{c}\text { Organic } \\
\text { matter }\end{array}$ & $\begin{array}{l}\text { Crude } \\
\text { protein }\end{array}$ & $\begin{array}{l}\text { Ether } \\
\text { extract } \\
\text { (as \% of }\end{array}$ & $\begin{array}{l}\text { Crude } \\
\text { fibre } \\
\text { dry matter) }\end{array}$ & $\begin{array}{l}\text { Nitrogen-free } \\
\text { extract } \\
\text { r) }\end{array}$ & \\
\hline & $(\%)$ & & & & & & \\
\hline Straw & $84 \cdot 3$ & $94^{\cdot I}$ & $2 \cdot 7$ & 0.9 & $43 \cdot 0$ & $47 \cdot 5$ & \\
\hline Hay & 85.0 & 93.7 & $7 \cdot 5$ & $1 \cdot 6$ & $33^{\cdot 6}$ & $51 \%$ & $6 \cdot 3$ \\
\hline Concentrate & 86.8 & 92.6 & $\begin{array}{l}19.9 \\
19.9\end{array}$ & $2 \cdot 3$ & 7.8 & 62.6 & $7 \cdot 4$ \\
\hline
\end{tabular}

The weight of each cow was determined by weighing on 2 consecutive days at the end of each treatment period. The cows were weighed after feeding, with the reticulorumen emptied.

\section{Determination of voluntary intake}

The total daily allowance of each food was offered in one meal at $10.00 \mathrm{~h}$. The uneaten food was removed and weighed after $5 \mathrm{~h}$. The amount of food offered was adjusted so that the uneaten portion was about 10\% of the amount offered.

\section{Digestibility}

The digestibility of the diets was determined by collecting the faeces with the harness and equipment described by Balch, Bartlett \& Johnson (I95I).

\section{Digestion of cellulose in the rumen}

The cotton thread technique described by Campling, Freer \& Balch (196r) was used to obtain an index of the rate of digestion of cellulose in the rumen. 


\section{Mean time of retention of food residues in the alimentary tract}

Immediately before feeding on the second day of each collection period on the straw diet, or on the 3 rd day when the other diets were given, about $4 \%$ of the daily intake of food was given stained with magenta or brilliant green, and the numbers of stained particles in subsequent samples of faeces were counted (Balch, 1950). The mean time of retention of stained particles in the gut was calculated by the method of Castle (1956).

\section{Amount of digesta in the reticulo-rumen}

The weight of digesta in the reticulo-rumen was measured by completely emptying the contents of that organ via the fistula, into stainless steel buckets, before and after feeding on 2 successive days at the end of each treatment period. The digesta were quickly weighed, sampled for dry-matter determination, and returned to the reticulorumen.

RESULTS

Body-weight

The mean weights (with reticulo-rumen empty) of the cows on each treatment are shown in Table 2.

Table 2. Mean live weights ( $k g$ ), with reticulo-rumen empty, of six cows when fat and when thin, given rations of straw, hay or hay plus concentrates

\begin{tabular}{lccc}
\multicolumn{1}{c}{ Diet } & Fat cows & Thin cows & $\begin{array}{c}\text { Difference } \\
\text { (fat-thin) }\end{array}$ \\
Straw & 573 & 396 & 177 \\
Hay & 615 & 415 & 200 \\
Hay plus concentrates & 642 & 487 & 155 \\
Mean & 610 & 433 & 177
\end{tabular}

Table 3. Mean daily voluntary intakes of straw, hay and hay plus concentrates by six cows when fat and when thin

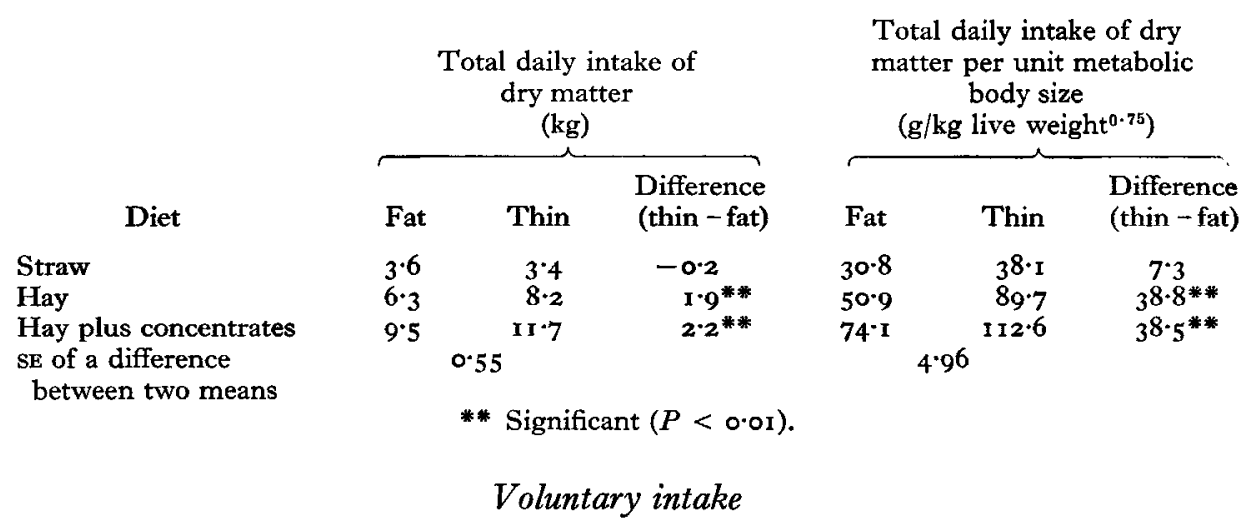

The mean daily voluntary intakes of straw, hay and hay plus concentrates by fat and thin cows during the ro-day measurement periods are shown in Table 3 . Due to the lack of information about the maintenance requirement of fat, some doubt exists as to 
the best manner of expressing these results, i.e. whether absolute terms or terms including metabolic body size (live weight ${ }^{0 \cdot 75}$ ) are preferable. Therefore both are presented in this paper.

There was no difference between fat and thin cows in their mean daily intakes of straw dry matter. On the hay and hay plus concentrate diets, the dry-matter intakes of the thin cows were, respectively, $3 \mathrm{r} \%$ and $23 \%$ greater than those of the fat cows. These differences were highly significant $(P<0 \cdot 01)$. In relation to metabolic body

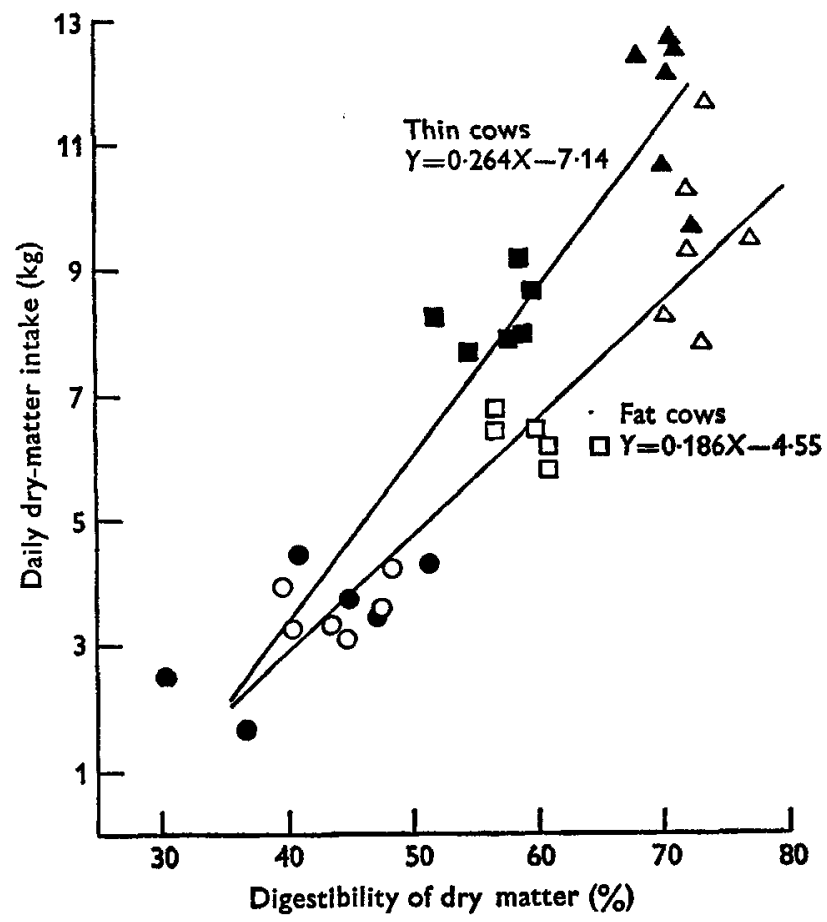

Fig. I. The relationship between the intake of dry matter and the digestibility of that dry matter when diets of straw $(\Theta 0)$, hay $(\square \square)$ or hay and concentrates $(\Delta \Delta)$ were fed to six cows when fat (open symbols) and when thin (solid symbols).

size, thin cows ate $76 \%$ more hay and $52 \%$ more concentrates, given with hay, than fat cows. In the terms used by Hutton (1963), the thin cows consumed $2 \cdot 40 \mathrm{~kg}$ dry matter per roo kg live weight per day when hay plus concentrates were given, and $1 \cdot 99 \mathrm{~kg}$ when hay was given alone. For the fat cows, the corresponding values were $\mathrm{I} \cdot 47 \mathrm{~kg}$ and $\mathrm{I} \cdot 02 \mathrm{~kg}$. These values are comparable to those of Hutton (1963) quoted at the beginning of this paper.

The three diets were consumed in significantly $(P<0.01)$ different quantities, there being a significant $(P<0$.0r) linear relationship between the digestibility of the diet and the amount of dry matter consumed (Fig. I). The size of these differences was significantly $(P<0.05)$ greater for thin cows than for fat cows and this is reflected in a significantly $(P<0.05)$ greater regression coefficient for thin cows than for fat cows in Fig. $r$. 
There were no significant differences between individual cows in a given state in the intake of a given diet.

\section{Digestibility}

All three diets were digested 2 or 3 percentage units less well by thin cows than by the fat animals (Table 4 ), and although the mean difference for each diet was in no instance statistically significant, the over-all difference between fat and thin cows was significant $(P<0.05)$. When the dry-matter intakes were corrected for these differences, however, the digestible intakes of hay and hay plus concentrates by the thin cows remained significantly $(P<0 \cdot 01)$ greater than those of the fat cows (columns 4 and 5 , Table 4).

Table 4. Apparent digestibilities of dry matter and mean daily digestible dry-matter intakes of straw, hay and hay plus concentrates given ad lib. to six cows when fat and when thin

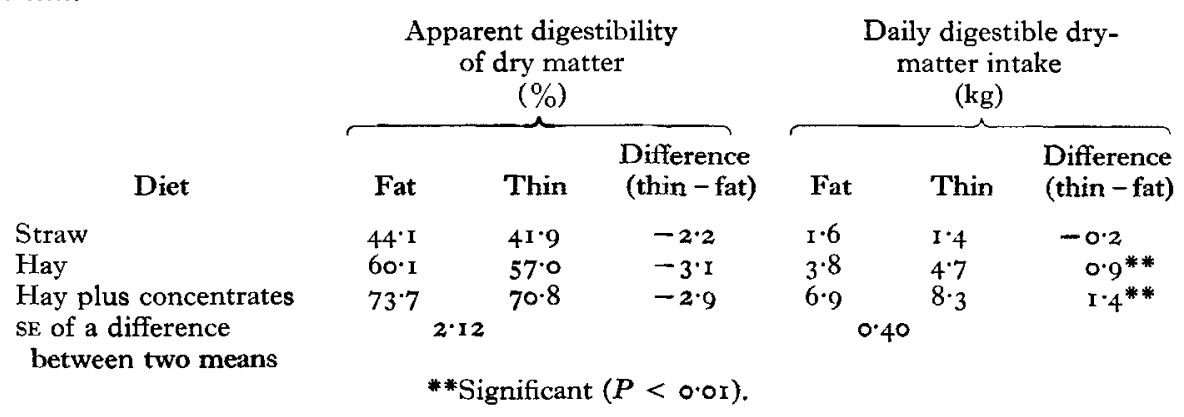

There was a very marked variation between animals in the digestibility of straw by the thin cows. Two cows, which had been given straw for 16 weeks, during which they were changing from fat to thin, ate very little at the end of this period; these low intakes were accompanied by very low digestibilities. This point is discussed further below.

There were highly significant $(P<0.01)$ differences between the digestibilities of the different diets, these differences being the same for both fat and thin cows.

\section{The rate of breakdown of cotton thread}

The rate of breakdown of cotton thread in the ventral sac of the rumen increased when hay was fed in place of straw, and increased again when concentrates were given with hay (Table 5). On a given diet, there were no significant differences between fat and thin cows in the time taken for cotton thread to lose $25 \%$ of its weight, though there was a tendency towards a reduced rate of breakdown in the thin cows given hay or hay and concentrates where the increased intake was also accompanied by a reduced digestibility.

On the hay and concentrate diet, in one cow when thin and in another when fat, there was no measurable loss of weight of cotton threads left in the ventral sac of the rumen for 7 days. The mean values shown in Table 5 are for the remaining five animals in each instance. 
Table 5. Mean rate of breakdown of cotton threads and the mean time of retention of stained food residues in the alimentary tract of six cows when fat and when thin, receiving straw, hay or hay plus concentrates ad lib.

\begin{tabular}{|c|c|c|c|c|}
\hline & \multicolumn{2}{|c|}{$\begin{array}{l}\text { Rate of breakdown of cotton } \\
\text { thread. Time for } 25 \% \text { loss } \\
\text { of weight } \\
\text { (h) }\end{array}$} & \multicolumn{2}{|c|}{$\begin{array}{l}\text { Mean time of retention* } \\
\text { of stained food } \\
\text { residues } \\
\text { (h) }\end{array}$} \\
\hline Diet & Fat & Thin & Fat & Thin \\
\hline Straw & 72 & 50 & 92 & 108 \\
\hline Hay & 39 & 46 & 78 & 72 \\
\hline Hay $\quad\}+$ & & & $85 \S$ & $87 \S$ \\
\hline Concentrates $\}$ & $28 I$ & 367 & 50 & 47 \\
\hline $\begin{array}{l}\text { SE of a difference } \\
\text { between two means }\end{array}$ & & & \multicolumn{2}{|c|}{$8 \cdot 2$} \\
\hline $\begin{array}{l}\text { *Calculated by th } \\
\dagger \text { Fed together. } \\
\ddagger \text { Means of five c } \\
\S \text { Only measured }\end{array}$ & $\begin{array}{l}\text { ethod of } \\
\text { only ( } \mathrm{n} \\
\text { hree cov }\end{array}$ & ight af & & \\
\hline
\end{tabular}

\section{The mean time of retention of undigested food residues}

Undigested residues of the straw diet, which was eaten in similar amounts by both groups of cows, were retained longer in the alimentary tract of thin cows than in that of fat cows (Table 5) though the difference was not significant. The hay diet and the concentrate portion of the mixed diet passed through the thin cows marginally, but not significantly, more quickly than through the fat cows. Residues from a small fixed quantity of hay given with ad lib. concentrates were retained significantly $(P<0.05)$ longer in the alimentary tract of thin cows than residues from hay given alone; in fat cows, this difference was not significant $(P>0.05)$.

Undigested residues of concentrates given with hay passed through the alimentary tract more quickly than hay residues which in turn passed more quickly than straw.

\section{Amount of digesta in the reticulo-rumen}

Before feeding, the weight of wet material in the reticulo-rumen of thin cows on the hay ration was significantly $(P<0.05)$ greater than that found in these animals when they were given the other two rations. On a given diet there were no differences between fat and thin cows. There were no significant differences between fat and thin cows or between diets in the amount of digesta dry matter in the reticulo-rumen before feeding.

When hay was fed alone to thin cows the total amounts of digesta and digesta drymatter in the reticulo-rumen immediately after a meal were significantly $(P<0.05)$ greater than when either of the other diets was given (Table 6). Also, the total amounts of digesta and digesta dry matter after a meal of hay were significantly $(P<0.05)$ greater in thin cows than in fat cows. After a meal of straw there were no differences between fat and thin cows in the amounts of digesta or digesta dry matter in the reticulorumen. Similarly, on the hay plus concentrate diet, there were no differences between 
the two groups of animals in either of these measurements though the digesta dry matter in both groups was significantly $(P<0.05)$ greater than when straw was fed. There were no significant $(P>0.05)$ differences in the amounts of digesta or of digesta dry matter in the reticulo-rumen of fat cows after being given hay or after hay plus concentrates. However, in four of the six animals there were substantial differences between the diets, the mean fill after eating hay being $88.4 \mathrm{~kg}$ ( $11 \cdot 0 \mathrm{~kg}$ dry matter) and after hay plus concentrates $76.5 \mathrm{~kg}$ (10.5 $\mathrm{kg}$ dry matter).

Table 6. Mean amounts of total digesta and digesta dry matter in the reticulo-rumen before and after giving diets of straw, hay or hay and concentrates to six cows when fat and when thin

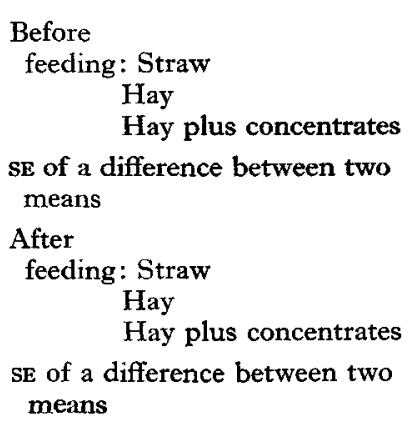

\begin{tabular}{|c|c|c|c|c|c|}
\hline \multicolumn{6}{|c|}{ Digesta in reticulo-rumen } \\
\hline \multicolumn{3}{|c|}{ Total (kg) } & \multicolumn{3}{|c|}{ Dry matter (kg) } \\
\hline Fat & Thin & $\begin{array}{l}\text { Difference } \\
\text { (thin - fat) }\end{array}$ & Fat & Thin & $\begin{array}{l}\text { Difference } \\
\text { (thin - fat) }\end{array}$ \\
\hline $\begin{array}{l}62 \cdot 6 \\
63 \cdot 8 \\
55 \cdot 6\end{array}$ & $\begin{array}{l}55 \cdot 5 \\
71 \cdot 6 \\
54 \cdot 0\end{array}$ & $\begin{array}{r}-7 \cdot 1 \\
7.8 \\
-\mathbf{I} \cdot 6\end{array}$ & $\begin{array}{l}6 \cdot 21 \\
5 \cdot 60 \\
5 \cdot 06\end{array}$ & $\begin{array}{l}5 \cdot 59 \\
7 \cdot 16 \\
5 \cdot 77\end{array}$ & $\begin{array}{r}-0.62 \\
1.56 \\
0.71\end{array}$ \\
\hline \multicolumn{2}{|c|}{$5 \cdot 54$} & \multicolumn{4}{|c|}{0.62} \\
\hline $\begin{array}{l}80 \cdot 8 \\
87 \cdot 7 \\
81 \cdot 0\end{array}$ & $\begin{array}{r}72 \cdot 7 \\
106 \cdot 5 \\
86 \cdot 5\end{array}$ & $\begin{array}{c}-8.1 \\
\text { I } 8.8 * \\
5.5\end{array}$ & $\begin{array}{r}9.17 \\
10.80 \\
10.76\end{array}$ & $\begin{array}{r}8 \cdot 73 \\
13 \cdot 89 \\
\text { I I } 33\end{array}$ & $\begin{array}{c}-0.44 \\
3.09^{*} \\
0.57\end{array}$ \\
\hline \multicolumn{2}{|c|}{6.19} & \multicolumn{4}{|c|}{0.71} \\
\hline
\end{tabular}

* Significant $(P<0.05)$.

\section{DISCUSSION}

In absolute terms, the thin cows ate, on average, $31 \%$ more hay and $23 \%$ more concentrates given with a small, fixed amount of hay, than did the same animals when fat. If differences in metabolic body size are taken into account, the intakes of the two diets by the thin cows were respectively $76 \%$ and $52 \%$ greater than those of the fat animals. Even allowing for the small depression in the digestibility of these diets in the thin animals, there were still substantial differences between the two groups in the amounts of digestible dry matter consumed. These observations suggest that regulation of food intake according to the degree of fatness is present in the dairy cow and is of considerable quantitative significance.

The existence of regulation by this means is not disproved by the fact that there was no difference between the intakes of straw by fat and thin cows. Egan \& Moir (1965) have shown that the intake of poor-quality roughages by ruminants is low and have suggested that this is due to a reduced ability to utilize acetate in animals in which protein reserves have been diminished (Egan, 1965). Before intake measurements were made in the present experiment three of the thin cows had been given straw for several weeks in order to change them from the fat to the thin state. As well as causing loss 
of fat, this treatment is also likely to have caused a depletion of these animals' protein reserves (Butterfield, 1966); two of these cows had markedly lower intakes than the other thin animals. The other thin animals also consumed straw for a longer time before the balance period, than the fat cows, which had only 14 days changeover. If there was a carryover effect from this treatment to the hay treatment in the thin cows, it would have been expected to have had a depressing effect on hay intake, yet even so, the thin cows consumed more hay than did the fat ones. Similarly, it seems unlikely that any carryover effect between other treatments in either group of animals would have caused an overestimation of the difference in intake between the two groups.

In the present experiment no attempt was made to measure the total amount of material which the rumen was capable of holding if it were completely filled, therefore it cannot be stated conclusively that the capacity of this organ limited the intake of the hay diet. However, the evidence of Freer \& Campling (1963) and Campling \& Freer (I966) suggests that rumen capacity may have been limiting, in which case it may be concluded from the values for rumen fill that the capacity of the reticulorumen of the thin cows was some $20 \%$ greater than that of the fat animals. Such a change in capacity could have come about by the loss of fat from within the abdominal cavity and particularly from around the gut itself when the fat animals lost weight. This difference would account for a large part of the increase in the intake of hay by the thin animals. The work of Russel, Gunn \& Doney (1968) with pregnant ewes has shown that fat is readily mobilized from omental and mesenteric depots during periods of undernutrition, and that these are capable of a decrease in size of more than $50 \%$. Riney (1955) described the order of mobilization of fat reserves in red deer during periods of undernutrition; omental and mesenteric fat were amongst the earlier depots to be mobilized. Further evidence for an increase in gut capacity is provided by the information on mean retention times which shows that the rate of passage of hay or concentrate residues through the alimentary canal of the thin cows was no greater than in the fat cows even though thin cows consumed significantly greater quantities of these feeds than did fat cows.

Immediately after a meal of hay and concentrates the amount of material in the reticulo-rumen of the thin cows was, on average, $20 \mathrm{~kg}$ less than when hay was given alone. This finding confirms that rumen fill is not a major factor influencing the intake by thin cows of diets high in concentrates. In the fat cows, the mean difference in rumen fill after giving the two rations was only $6.7 \mathrm{~kg}$, although in four of the six cows this difference was considerably larger, suggesting the existence of a factor of greater importance than rumen fill in controlling the intake of high-concentrate diets by fat cows also. Freer \& Campling ( 1963$)$ have proposed that the concentration of some unidentified products of digestion limited the intake of cows given a concentrate diet. It seems probable that a similar type of mechanism was operating in the present experiment and that it was flexible in its operation, permitting the thin cows to consume greater amounts of the high-concentrate diet than the fat cows. This flexibility may have resulted from the thin cows being able to tolerate higher concentrations of digestion products or may, alternatively, have been due to a greater rate of utilization of these products by thin cows, thus permitting a greater rate of production in the 
maintenance of a fixed critical level. Howarth, Baldwin \& Ronning (I968) have stated that physiological states are significant factors determining the metabolic activity of bovine adipose tissue. Therefore it is possible that the adipose tissue of thin cows would have a greater capacity than that of fat cows for lipid synthesis, thus causing a greater rate of utilization of lipogenic substrates. This is different from the mode of operation of a lipostatic mechanism envisaged by Kennedy (r953) in that uptake by, rather than output from, adipose tissue is involved; it must be acknowledged, nevertheless, that the results of the present experiment do not preclude the operation of a mechanism whereby the adipose tissue releases a food intake inhibitor. Regardless of its mode of operation, however, a physiological mechanism, whereby food intake is influenced by the fatness of the animal, does appear to operate in cows and is of considerable quantitative significance in the regulation of the intake of concentrate diets; the operation of a physical mechanism may provide a better explanation of the differences in intake of roughages such as hay.

We thank Dr R. C. Campling for his advice, MrV.W. Johnson and his colleagues for care of the experimental animals and for assistance with rumen emptyings and members of the Chemistry Department for analysis of the feeds.

\section{REFERENCES}

Balch, C. C. (1950). Br. F. Nutr. 4, 36r.

Balch, C. C., Bartlett, S. \& Johnson, V. W. (195r). F. agric. Sci., Camb. 4I, 98.

Butterfield, R. M. (1966). Res. vet. Sci. 7, 168 .

Campling, R. C. \& Freer, M. (1966). Br. F. Nutr. 20, 229.

Campling, R. C., Freer, M. \& Balch, C. C. (196r). Br. F. Nutr. 15, 53 I.

Castle, E. J. (1956). Br. F. Nutr. Io, I5.

Conrad, H. R., Pratt, A. D. \& Hibbs, J. W. (1964). F. Dairy Sci. 47, 54.

Egan, A. R. (1965). Aust. F. agric. Res. 16, 473.

Egan, A. R. \& Moir, R. J. (1965). Aust. F. agric. Res. 16, 437.

Freer, M. \& Campling, R. C. (1963). Br. F. Nutr. 17, 79.

Howarth, R. E., Baldwin, R. L. \& Ronning, M. (1968). F. Dairy Sci. 51, 2270.

Hutton, J. B. (1 963). Proc. N.Z. Soc. Anim. Prod. 23, 39.

Kennedy, G. C. (I953). Proc. R. Soc. B I40, 578.

Riney, T. (1955). N.Z. Yl Sci. Tech. 36B, 429 .

Russel, A. J. F., Gunn, R. G. \& Doney, J. M. (1968). Anim. Prod. тo, 43.

Schinckel, P. G. (1 960). Aust. F. agric. Res. x, 585 . 